\title{
Comparison of Speed, Agility, Anaerobic Strength and Anthropometric Characteristics in Male Football and Futsal Players
}

\author{
Reşat Kartal \\ Correspondence: Reşat Kartal, School of Physical Education and Sport, Adnan Menderes University, Turkey
}

Received: March 7, 2016 Accepted: March 28, 2016 Online Published: April 4, 2016

doi:10.11114/jets.v4i7.1435

URL: http://dx.doi.org/10.11114/jets.v4i7.1435

\begin{abstract}
The purpose of this study is to compare speed, agility, anaerobic strength and some anthropometric characteristics in male football and futsal players. The sample of the study is composed of male futsal team players of Aydin Adnan Menderes University (19-24 aged) ( $\mathrm{n}=12)$ and Aydın Merkez Yeniköy Football Club players (19-24 aged) (n=12). Within the scope of the study, the following techniques were applied: 30-meter speed test for determining speeds of the players, Illinois agility test for determining agility of the players, Sargent jump test for determining anaerobic strengths of the players, height weight measurement and body-mass index (B.M.I) for determining anthropometric characteristics of the players.

The players were informed of the test protocols before the tests and they were voluntary for attending the study. The players attending the research did not experience any injury problem for the last 8 months and none of the players experienced any injury problem during the tests.

Statistical analysis of the tests was conducted by using independent sample t-test in SPSS 20.00 program. After the tests, it was found that there was a significant difference in favor of futsal players in speeds of male futsal and football players and there was a significant difference in favor of football player in anaerobic strengths $(p<0,05)$ while there was not any significant difference statistically in agility test $(p>0,05)$. As a result, there was significant difference among values regarding speed, anaerobic strength and anthropometric characteristics of male futsal and football players while there was not a significant difference in agility values.
\end{abstract}

Keywords: futsal, football, speed, agility, anaerobic strength

\section{Introduction}

Today, football is by far the most popular sports branch in the world and likewise, futsal is also becoming a popular sports branch rapidly (Roxburg, 2008). These two sports branches possess very similar features (Milanoviç et al., 2011). Both sports branches are played in intensive tempo and they require not only aerobic but also much more anaerobic strength (Barbero-Alvarez et al., 2008). Workout capacity showing up through the use of anaerobic energy transfer systems of skeletal muscles during maximal and submaximal physical activity is defined as "anaerobic capacity". Anaerobic workout is a type of physical activity which means revealing explosive power, which is a workload over anaerobic threshold value and which manifests itself with fatigue. It is impossible to continue anaerobic activity for a long time (Yıldiz, 2012). Team sports like Football and Futsal include different actions which should be performed in a short time such as jumping, jogging, and running towards different directions, juking and changing direction during the match. Athletes display intensive contention in these kinds of sports branches (Makaje et al., 2012). Athletes generally display maximal or submaximal efforts and make 1-7 seconds of short sprints (Bradley et al., 2009). Speed is one of the most important motoric features for many sports branches. Therefore, it must be improved at early ages (Polat, 2009). Speed is defined as the ability of an athlete to move himself/herself from one place to another with maximum velocity or to perform the moves with maximum velocity. Indeed, maximum heartbeat density can generally reach up to $90 \%$ levels in futsal matches. Thus, the characteristic of sprint is one of the most important motor characteristics for futsal players (Nascimento et al., 2014). High speed actions during football competition are categorized by dividing them into moves requiring acceleration, maximal speed or agility (Little and Williams, 2005). Futsal player also needs quick strength in very high level in order to move and change place fast within the game, to increase in number in defense and forward, to be effective in one-to-one, to cover distance with/without ball in defense and forward and to exhibit a good technical skill and tactical play (Göral, 2014). Agility is a necessary important physical component for a successful 
performance in football and futsal like in many other sports branches (Ellis et al., 2000). In futsal, the fact that one-to-one tactical space is generally narrow and ball is heavier, this develops defense and forward power technique of the player and enables him/her to decide faster (Burns, 2003). While players realize 146 tactical moves in narrow space plays in football, this number is 536 in futsal. It can be said that this numerical difference is caused by the fact that forward players should possess ball control and break the symmetry of angles and distances among defense players in order to impose position superiority and score in Futsal (Alvurdu, 2013). Therefore, level of agility is more important in futsal players when compared to football players (Milanoviç et al., 2011). Agility is the physical ability to apply deceleration, changing direction, acceleration in a very short time efficiently (Verstegan et al., 2001). Agility is also the basic component determining quality of the moves of a football player such as changing direction in high speed runs, sudden acceleration and stop and when it is compared with the general population, it is a feature distinguishing an elite sportsman according to other field tests such as strength, power and flexibility (Hazır et al., 2010). Moves and ground-direction swift practices to be applied in the training are the training types improving agility (Taheri et al., 2014).

Human body is composed of muscles, lipids and bones in different ratios and densities. These components affect performance in different ratios depending on sports branches. Effective test programs show whether players are suitable for the related sports branch or not physically. Therefore, sports scientists have heavily focused on studying body compositions and physical profiles of the players as well as their physiological profiles (Albay et al., 2008). The anthropometric and physiological examinations contribute to the preference of the player and the training model to be applied as well as forming a foresight in the targeted success. Today, sportsmen should be faster, more skillful, higher quality in terms of anthropometric and physiological capacities in all sports branches (Ersöz et al., 1996).

Anthropometric characteristics can be determinative in enhancing or determining performance and ability level (Reilly et al., 2000).

Speed, agility, anaerobic strength and anthropometric structure are some of the most important characteristics of the players in sports branches like futsal and football which are generally played in intensive tempo with sudden accelerations and sudden directions swifts. And the main sports branches in which the abovementioned characteristics are used are football and futsal.

As a result, this study was carried out in order to determine speed, agility, anaerobic strength and some anthropometric characteristics of male football and futsal players.

\section{Material and Method}

Subject group of this study was composed of 24 volunteer sports players in total specifically 12 futsal team players of Adnan Menderes University which played semi-final in Turkish championship and 12 football players from Aydın super amateur league teams. The measurements were carried out in relaxing days of the sports players within the competition period. Speed, agility, Sargent jump and anthropometric measurements of the players were conducted in sports facilities of Adnan Menderes University. Sports players were informed about the measurements and were asked if they had experienced any injury before. After medical check-ups were made, the measurements were performed.

Speed test: 30 -meter speed test was applied on the subjects. Test was performed by determining a 30-meter distance and making the sports players run from a starting point and measurement was performed with chronometer (Ulusoy, 2013).

Illinois agility test: A test racetrack composing of three cones which were placed on a straight line whose width was 5 meters, length was 10 meters and 3.3 meters intervals were placed in the middle were set into the gym. Test was composed of slalom run 20-meter of which was among cones, 40-meter of which was straight and which included $180^{\circ}$ turns in every 10 meters. After test racetrack was prepared, two-door photocell electronic chronometer system measuring in 0.01 seconds sensitivity to start and finish was placed. Subjects started to run from starting point of test racetrack in facedown position and hands in shoulder-length and hands in contact with the ground. Finish time of the racetrack was recorded with second basis (Karacabey, 2013; Hazır, 2010).

Anaerobic strength: Anaerobic strength test was performed by using Sargent jumping board. The last point contacted by fingertips through stretching two arms up while keeping the feet together and standing upright was marked on the board and then the subject contacted the board by jumping upwards full steam ahead with his/her two feet. The subjects did not take step while jumping upwards and bended their knees $90^{\circ}$. After three repeats, the best result was recorded (Taskin et al., 2015).

(Sargent jump $=\mathrm{P}=(\sqrt{ } 4.9$ Weight $\sqrt{ } \mathrm{D}) \mathrm{kgm} / \mathrm{s})$ (Sargent, 1921).

Anaerobic Endurance: In speedy, dynamic, very high and maximal loadings, an organism is capable of performing any sportive activity benefiting from energy sources in body (Şahin,2004). 
Height and body weight: Weight was measured in $0,1 \mathrm{~kg}$ sensitivity through an electronic bascule while height was measured in 0,01 cm sensitivity through a digital measuring tool (Tamer, 2000).

Body-mass index (BMI): The following formula was used in order to determine body-mass index (Tamer, 2000; Zorba and Saygin, 2009).

Body-Mass Index $($ BMI $)=$ Body Weight $/$ Height $(\mathrm{m}) 2$

Statistical Analysis: SPSS 20.00 packet program was used as statistical analysis in our study. Independent Sample T Test was applied in order to determine analysis correlation among measurements. Values lower than $\mathrm{p}(0<0.5)$ were accepted as having significant difference.

\section{Findings}

Table 1. Descriptive Statistics of the Players

\begin{tabular}{llll}
\hline Variables & & Number & $\%$ \\
\hline \multirow{3}{*}{ Branch } & Football & 12 & 50 \\
& Futsal & 12 & 50 \\
\cline { 2 - 4 } Age Group & Total & 24 & 100 \\
\cline { 2 - 4 } & $19-20$ & 7 & 29.2 \\
& $21-22$ & 13 & 54.2 \\
\multirow{3}{*}{ Sports Age } & $23-24$ & 4 & 16.7 \\
\cline { 2 - 4 } & Total & 24 & 100 \\
\cline { 2 - 4 } & $2-6$ & 6 & 25 \\
& $7-9$ & 10 & 51.7 \\
\hline
\end{tabular}

Some descriptive statistics of the players attending the study are seen in Table 1.

Table 2. Minimum and Maximum Values regarding Some Anthropometric Characteristics of the Players

\begin{tabular}{llllll}
\hline Variables & Lowest & Highest & $\begin{array}{l}\text { Arithmetic } \\
\text { Average }\end{array}$ & $\begin{array}{l}\text { Standard } \\
\text { Deviation }\end{array}$ & Median \\
\hline Height $(\mathrm{cm})$ & 1.67 & 1.88 & 1.74 & 0.06 & 1.72 \\
Weight $(\mathrm{kg})$ & 62 & 83 & 70.08 & 5.84 & 68.5 \\
BMI $\left(\mathrm{kg} / \mathrm{m}^{2}\right)$ & 20.24 & 25.10 & 23.11 & 1.07 & 23.2 \\
\hline
\end{tabular}

In Table 2, values acquired from the measurements which have been conducted in order to determine some anthropometric characteristics of the players attending the study are seen. Observation number for all parameters in the Table is 24 .

Table 3. Comparison of Some Anthropometric Characteristics of the Players

\begin{tabular}{|c|c|c|c|c|c|c|}
\hline Variables & Branch & $\mathrm{N}$ & $\mathrm{X}$ & SS & $\mathrm{t}$ & $\mathrm{p}$ \\
\hline \multirow{2}{*}{ Height $(\mathrm{cm})$} & Football player & 12 & 1.76 & 0.07 & \multirow{2}{*}{2.418} & \multirow{2}{*}{$0.028 *$} \\
\hline & Futsal player & 12 & 1.71 & 0.03 & & \\
\hline \multirow[t]{2}{*}{ Weight (kg) } & Football player & 12 & 72.75 & 6.62 & \multirow{2}{*}{2.471} & \multirow{2}{*}{$0.025 *$} \\
\hline & Futsal player & 12 & 67.42 & 3.47 & & \\
\hline \multirow[t]{2}{*}{ BMI $\left(\mathrm{kg} / \mathrm{m}^{2}\right)$} & Football player & 12 & 23.20 & 0.84 & \multirow{2}{*}{0.405} & \multirow{2}{*}{0.689} \\
\hline & Futsal player & 12 & 23.02 & 1.29 & & \\
\hline
\end{tabular}

Significance in $p<0.05$ level

When Table 3 is examined, a significant difference between football players and futsal players is seen in terms of height and weight $(\mathrm{p}<0.05)$ while there is not any difference between football players and futsal players in terms of BMI values $(\mathrm{p}>0.05)$.

Table 4. Comparison of Speed, Agility and Anaerobic Strength of the Players

\begin{tabular}{|c|c|c|c|c|c|c|}
\hline Variables & Branch & $\mathrm{N}$ & $\mathrm{X}$ & SS & $\mathrm{t}$ & $\mathrm{p}$ \\
\hline \multirow{2}{*}{ Speed (s) } & Football player & 12 & 4.39 & 0.14 & \multirow{2}{*}{2.302} & \multirow{2}{*}{$0.030^{*}$} \\
\hline & Futsal player & 12 & 4.27 & 0.11 & & \\
\hline \multirow{2}{*}{ Agility (s) } & Football player & 12 & 10.96 & 0.32 & \multirow{2}{*}{1.416} & \multirow{2}{*}{0.169} \\
\hline & Futsal player & 12 & 10.78 & 0.34 & & \\
\hline \multirow{2}{*}{ Anaerobic strength $(\mathrm{cm})$} & Football player & 12 & 34.33 & 3.35 & \multirow{2}{*}{9.354} & \multirow{2}{*}{$0.000 *$} \\
\hline & Futsal player & 12 & 24.66 & 1.37 & & \\
\hline
\end{tabular}

* Significance in $p<0.05$ level

In Table 4, it is seen that there is a significant difference in favor of futsal players when speed characteristics of football and futsal players are compared $(\mathrm{p}<0.05)$. However, it is understood that there is not any significant difference among the 
players in terms of agility characteristics $(\mathrm{p}>0.05)$.

\section{Discussion and Conclusion}

Some physical and physiological requirements are needed as well as technical and tactical skills in order to be successful in football and futsal. Due to the fact that today's football is based on physical strength and speed, some of the most important requirements are speed, agility and anaerobic strength. Furthermore, these characteristics are some of the most important features within the futsal game because of the game character of futsal.

Thus, in this study in which speed, agility, anaerobic strength and some anthropometric characteristics of male futsal and football players were assessed, a significant difference was found statistically between football and futsal players in terms of speed and anaerobic strength while there was not a significant difference between them in terms of agility (Table 4).

When the speed pretest and posttest values were examined in our study, it was found a significant difference in favor of futsal players $(\mathrm{p}<0.05)$.

In a study conducted by Matos et al. in 2008, it was found a significant difference in 10-meter speed test in favor of futsal players. Also in this study, it was seen that there was a significant difference in speed values in favor of futsal players.

In a study conducted by Cuadrado et al. in 2014 regarding sprint speed of professional football and futsal players, it was stated that there was a significant difference in favor of futsal players in terms of speed.

In a study conducted by Zerguini et al. in 2007 regarding Ramadan month's affecting physical conditions of football players, similarities was found in speed values between two studies. However, there are findings similar to our values in Zerguini's study in which there are significant difference in favor of futsal players.

In a study conducted by Gökhan et al. (2015) regarding leg strength and speed of amateur football players, there were similarities between speed values of that study and our study.

In a study conducted by Ünveren in 2015 regarding agility and speed of female futsal and football players, it was stated that there was a significant difference between female futsal and football players in speed test.

In a study conducted by Sanjun et al. in 2015 regarding anthropometric structure and physical fitness levels of elite level futsal players and elite football players playing in Chinese Super League, it was found a significant difference in average sprint speeds.

In a study conducted by Aziz et al. in 2000 regarding comparison of sprint speed and maximal oxygen of field hockey and football players, sprint speed values of football players showed closeness to our values.

When pretest-posttest values of experimental group and control group in our study were examined, no any significant difference was found in agility values $(\mathrm{p}<0.05)$.

In a study conducted by Milanovic et al. in 2011 regarding male football and futsal players, it was stated that there was not a significant difference between their agility levels. In our study, there was not a significant difference in agility values.

In a study conducted by Bloomfield et al. in 2007 regarding agility levels of football players playing in Premier League, although football players showed a better agility characteristic compared to futsal players, there was not a significant difference.

In a study conducted by Göral in 2014 regarding acceleration and agility characteristics of futsal and football players, it was not found a significant difference in agility values of futsal and football players.

Agility values found in the study conducted by Letona et al. in 2015 regarding agility levels of football players showed similarities with our study.

In a study conducted by Galy et al. in 2015 regarding anthropometric and physiological structures of futsal players in Malaysia League, agility values of the futsal players were found to be similar with the values in our study.

When pretest-posttest values of experimental group and control group in our study were examined, a significant difference was found in favor of football players $(\mathrm{p}<0.05)$.

In a study conducted by Cuadrado et al. in 2014 regarding professional football and futsal players, it was specified that there was a significant difference between football and futsal players in Sargent jumping test.

In a study conducted by Gorostiaga et al. in 2009 regarding physical fitness of futsal and football players, a significant difference was found in favor of football players in anaerobic strength relationship in Sargent jumping test. 
Height average of football players attending our study was $1.76 \pm \mathrm{cm}$, their average body weight was $72.75 \pm \mathrm{kg}$ while height average of the futsal players was $1.71 \pm \mathrm{cm}$ and their average weight was $67.42 \pm \mathrm{kg}$.

Barbero-Alvarez et al. (2009) determined that body weight of semi-professional Italian futsal players was $69.8 \pm 6.6$ while their height was $175 \pm 4.2 \mathrm{~cm}$.

Göral et al. (2009) found that average height of futsal players was $175.5 \pm 2.85 \mathrm{~cm}$, their average body weight was $71.7 \pm 3.21 \mathrm{~kg}$; height average of football players was $175.7 \pm 3.88$ and their average body weight was $73.2 \pm 4.04 \mathrm{~kg}$. When we compared our study with the study of Göral, similar values were acquired within the scope of this study.

Hazır et al. (2010) found height average of young football players as $172.4 \pm 6.4$ while they found body weight of them as $62.20 \pm 5.5 \mathrm{~kg}$.

Milanovic et al. (2011) found that average height of football players was $175.42 \pm 5.95 \mathrm{~cm}$ while their body weight was $70.86 \pm 5.65 \mathrm{~kg}$; average height of futsal players was $176 . \pm 6.85 \mathrm{~cm}$ while their body weight was $70.39 \pm 5.33 \mathrm{~kg}$.

In the study conducted by Russell et al. (2011), average height of football players was $175 \pm 0.05 \mathrm{~cm}$ while their average body weight was $71.0 \pm 8.04$.

When the literature studies were examined, findings of this study show similarities in both football and futsal players.

Consequently, significant differences were observed in favor of futsal players in speed and in favor of football players in anaerobic strength and anthropometric characteristics due to the fact that physical structures of futsal and football players were different. The fact that there was not any significant difference in their agility levels was thought to be depending on both games' including moving towards different directions and fast turns. It is though agility trainings should take place more frequently in order to develop agility characteristic which is needed in both sports branches.

\section{References}

Albay, M., Tutkun, E., Ağaoğlu, Y. S., Canikli, A., \& Albay, F. (2008). Hentbol, Voleybol ve Futbol Üniversite Takımlarının Bazı Motorik ve Antropometrik Özelliklerinin İncelenmesi. Spormetre Beden Eğitimi ve Spor Bilimleri Dergisi, 6(1), 13-20. http://dx.doi.org/10.1501/Sporm_0000000129

Alvurdu, S. (2013). Uefa Futsal Euro 2012: Türkiye Futsal Milli Takımının Grup Maçları Teknik ve Taktik Analizi. Pamukkale Journal of Sport Science, 4(4), 104-110. http://psbd.pau.edu.tr/article/view/1062000226

Barbero-Alvarez, C. J., D'ottavio, S., Vera, J. G., \& Castagna, C. (2009). Aerobic Fitness in Futsal Players of Different Competitive Level. Journal of Strength and Conditioning Research, 23(7), 2163-2166. http://dx.doi.org/10.1519/JSC.0b013e3181b7f8ad

Barbero-Alvarez, J. C., Soto, V. M., Barbero-Alvarez, V., \& Granda-Vera, J. (2008). Match analysis and heart rate of futsal players during competition. Journal of Sports Sciences, 26, 63-73. http://dx.doi.org/10.1080/02640410701287289

Bloomfield, J., Polman, R., \& O’Donoghue. (2007). Physical demands of different positions in FA premier league soccer. Journal of Sports Science and Medicine, 6, 63-70. http://www.jsportscimed.org/vol6/n1/8/v6n1-8pdf.pdf

Bradley, P. S., Di Mascio, M., Peart, D., Olsen, P., \& Sheldon, B. (2009). High-intensity activity profiles of elite soccer players at different performance levels. Journal of Strength and Conditioning Research, 24, 2343-2351.

Burns, T. (2003). Holistic futsal: a total mind-body-spirit approach. New York: Lulu

Ersöz, G., Koz, M., Sunay, H., \& Gündüz, N., (1996). Erkek Voleybol Oyuncularının Sezon Öncesi, Sezon Ortası ve Sezon Sonu Fiziksel Uygunluk Düzeyi Parametrelerindeki Değişmeler. Gazi University Beden Eğitimi ve Spor Bilimleri Dergisi, 1(4), 1-7. http://dergipark.ulakbim.gov.tr/inubesyo/article/view/5000119612/pdf_16

Galy, O., Zongo, P., Chamari, K., Chaouachi, A., Dellal, A., Castagna, C., \& Hue, O. (2015). Anthropometric and physiological characteristics of Melanesian futsal players: a first approach to talent identification in Oceania. Biology of Sport, 32, 135-141. http://dx.doi.org/10.5604/20831862.1140428

Gökhan, İ., Aktaş, Y., \& Aysan, H. A. (2015). Amatör Futbolcuların Bacak Kuvveti İle Sürat Değerleri Arasındaki İlişkinin incelenemesi. International Journal of Science Culture and Sport, (4), 47-54. 10.14486/IJSCS356

Göral, K. (2014). Futsal Oyuncuları ve Futbolcularda Sprint Sürati, Anaerobik Güç ve Dikey Sıçrama İlişkisinin İncelenmesi. Akademik Bakı̧ Dergisi, (40) ISSN: 1694-528.

http://www.akademikbakis.org/dergi//futsal-oyunculari-ve-futbolcularda-sprint-surati-anaerobik-guc-ve-dikey-sicr ama-iliskisinin-incelenmesi201401.pdf

Göral, K. (2014). Futsal Oyuncuları ve Futbolcularda İvmelenme ve Çeviklik Özelliklerinin İncelenmesi. Akademik Spor Sağlık ve Tip Bilimleri Dergisi, 10(4), 98-105. 
http://www.sstbdergisi.com/eng/?sayfa=dergiayrinti\&no=109\&icerik=futsal-oyunculari-ve-futbolcularda-ivmelen me-ve-ceviklik-ozelliklerinin-incelenmesi\&kategori=spor-bilimleri.

Gorostiaga, M., Llodio I., Ibanez J., Granados, G., Navarro, I., Ruesta, M., Bonnabau, H., \& Izguierdo, M. (2009). Differences in Physical Fitness among Indoor and Outdoor Elite Male Soccer Players. Eur J Appl Physiol, 106(4), 483-491. http://dx.doi.org/10.1007/s00421-009-1040-7

Hazır, T., Mahir, Ö. F., \& Açıkada, C., (2010). Genç futbolcularda çeviklik ile vücut kompozisyonu ve anaerobik güç arasındaki ilişki. Hacettepe J. of Sport Science, 21(4), 146-153. http://www.sbd.hacettepe.edu.tr/fulltext/2010_4_3.pdf.

Karacabey, K. (2013). Sporda performans ve çeviklik testleri. International Journal of Human Sciences, 10(1), 1693-1704. https://www.j-humansciences.com/ojs/index.php/IJHS/article/view/2653/1157.

Letona-Bidaurrazaga, I., Carvalho, H. M., Lekue, J. A., Badiola, A., Figueiredo, J. A., \& Gil, M. S. (2015). Applicability of an Agility Test in Young Players in the Soccer Field. Revista Brasileira de Medicana do Esporte, 21(2), 133-138. http://dx.doi.org/10.1590/1517-869220152102144406

Little, T., \&Williams, A. G. (2005). Specificity of acceleration, maximum speed, and agility in professional soccer players. Journal of strength and conditioning research, 19(1), 76-78.

http://journals.lww.com/nsca-jscr/Abstract/2005/02000/Specificity_of_Acceleration,Maximum_Speed,_and.13.asp $\mathrm{x}$.

Makaje, N., Ruangthai, R., Arkarapanthu, A., \& Yoopat, P. (2012). Physiological demands and activity profiles during futsal match play according to competitive level. J. Sports Med Phys Fitness, 52(4), 366-374. https://www.researchgate.net/publication/230564763_Physiological_demands_and_activity_profiles_during_futsal _match_play_according_to_competitive_level.

Matos, B. A. J., Aidar, J. F., Mendes, R. R., Lamal, M. L., Santos, A. C., Pains, R., Silva, A. J., \& Reis, V. M. (2008). Acceleration Capacity in Futsal and Soccer Players. Fitness Performance, 7(4), 224-228. http://dx.doi.org/10.3900/fpj.7.4.224.e

Milanović, Z., Sporiš, G., Trajković, N., \& Fredi Fiorentine, F. (2011). Differences Agility Performance between Futsal and Soccer Players. Sport Science, 4(2), 55-59.

https://www.researchgate.net/publication/220009739_Differences_in_agility_performance_between_futsal_and_so ccer_players.

Nascimento, P. C., Lucas, R. D., Pupo, J. D., Arins, F. B., Castagna, C., \& Guglielmo, L. G. A. (2014). Effects of Four Weeks of Repeated Sprint Training on Physiological Indices in Futsal Players. Revista Brasileira de Cineantropometria \& Desempenho Humano, 17(1), 91-103. http://dx.doi.org/10.5007/1980-0037.2015v17n1p91

Penaflel, C., Parraga-Montila, J., Ortega-Becerra, M. A., \& Jimenez-Reyes, P. (2014). Repeated Sprint Ability in Professional Soccer vs. Futsal Players. Journal of Sport Science, 10(2), 89-98. https://webcache.googleusercontent.com/search?q=cache:v-pYRNF9kYAJ:https://dialnet.unirioja.es/descarga/artic ulo/4869192.pdf $+\& \mathrm{~cd}=1 \& \mathrm{hl}=\mathrm{tr} \& \mathrm{ct}=\mathrm{clnk} \& \mathrm{gl}=\mathrm{tr} \& \mathrm{client}=\mathrm{safari}$

Polat, G. (2009). 9-12 Yaş Grubu Çocuklarda 12 Haftalık Temel Badminton Eğitimi Antrenmanlarının Motorik Fonksiyonları Ve Reaksiyon Zamanları Üzerine Etkileri.. (Unpublished master's thesis). T.R. Çukurova University Institute of Health Sciences Department of Physical Education and Sports, Adana.

Reilly, T., Bangsbo, J., \& Franks, A. (2000). Anthropometric and Physiological Predispositions for Elite Soccer Players. Journal of Sports Sciences, 18(9), 669-683. http://dx.doi.org/10.1080/02640410050120050

Roxburgh, A. (2008). The technician futsal. Newsletter for coaches. Nyon: Uefa.

Şahin, H. M. (2004). Beden Eğitimi ve Sporda Temel Kavramlar Sözlüğü, Geliştirilmiş 2. Baskı, Ankara: Nobel Yayın Dağıtım.

Sanjun, Y., Weike, Z., \& Xiaoke, C. (2015). Differences in Anthropometric and Physical Fitness between Futsal League Elite Male Players and Chinese Football Association Super League Elite Male Players. Journal of Wuhan Institute of Physical Education, 49(5), 96-100. http://www.whtyxb.cn/CN/abstract/abstract12689.shtml.

Sheppard, J. M., \& Young, W. B. (2006). Agility literature review: classifications, training and testing. Journal of Sports Sciences, 24, 919-932. http://dx.doi.org/10.1080/02640410500457109.

Tamer, K. (2000). Sporda Fiziksel- Fizyolojik Performans Ölçülmesi ve Değerlendirilmesi. Ankara: Bağırgan Yayımevi.

Taskin, C., Karakoc, O., Acaroglu, E., \& Budak, C. (2015). Futbolcu çocuklarda seçilmiş motorik özellikler arasındaki 
iliş̧kinin incelenmesi. Spor ve performans araştırmaları dergisi, 6(2), 101-107. http://dx.doi.org/10.17155/spd.74072

Ünveren, A. (2015). Investigating Women Futsal and Soccer Players Acceleration, Speed and Agility Features. Anthropologist. 21(1-2), 361-365.

http://krepublishers.com/02-Journals/T-Anth/Anth-21-0-000-15-Web/Anth-21-1-2-000-15-Abst-PDF/T-ANTH-211,2-361-15-1339-Unveren-A/T-ANTH-21-1,2-361-15-1339-Unveren-A-Tx[39].pdf

Yıldız, S. (2012). Aerobik ve Anaerobik Kapasitenin Anlamı Nedir? Solunum Dergisi. 14(1), 1-8. http://www.journalagent.com/eurasianjpulmonol/pdfs/SOLUNUM_14_SUP_1_1_8.pdf

Zerguini, Y., Kirkendall, D., Junge, A., \& Dvorak, J. (2007). Impact of Ramadan on physical performance in professional soccer players. Br. J. Sports Med., 41(6), 398-400. http://dx.doi.org/10.1136/bjsm.2006.032037

Zorba, E., \& Saygın, Ö. (2009). Fiziksel Aktivite ve Uygunluk. Ankara: İnceler Ofset.

This work is licensed under a Creative Commons Attribution 3.0 License. 